The Canadian Mineralogist

Vol. 41, pp. 473-478 (2003)

\title{
ON THE ASSOCIATION OF PALLADIUM-BEARING GOLD, HEMATITE AND GYPSUM IN AN OURO PRETO NUGGET
}

\author{
AleXANDRe RAPHAEl CABRAL ${ }^{\S}$ AND BERND LEHMANN \\ Institut für Mineralogie und Mineralische Rohstoffe, Technische Universität Clausthal, \\ Adolph-Roemer-Str. 2A, D-38678 Clausthal-Zellerfeld, Germany \\ ROGERIO KWITKO-RIBEIRO ${ }^{\S}$ \\ Centro de Desenvolvimento Mineral, Companhia Vale do Rio Doce, Rodovia BR 262/km 296, \\ Caixa Postal 09, 33030-970 Santa Luzia - MG, Brazil \\ RICHARD D. JONES \\ 1636 East Skyline Drive, Tucson, Arizona 85178, U.S.A. \\ ORLANDO G. ROCHA FILHO \\ Mina do Gongo Soco, Companhia Vale do Rio Doce, Fazenda Gongo Soco, \\ Caixa Postal 22, 35970-000 Barão de Cocais - MG, Brazil
}

\begin{abstract}
An ouro preto (black gold) nugget from Gongo Soco, Minas Gerais, Brazil, has a mineral assemblage of hematite and gypsum hosted by Pd-bearing gold. The hematite inclusion is microfractured and stretched. Scattered on the surface of the gold is a darkcolored material that consists partially of $\mathrm{Pd}-\mathrm{O}$ with relics of palladium arsenide-antimonides, compositionally close to isomertieite and mertieite-II. The $\mathrm{Pd}-\mathrm{O}$ coating has considerable amounts of $\mathrm{Cu}, \mathrm{Fe}$ and $\mathrm{Hg}$, and a variable metal:oxygen ratio, from O-deficient to oxide-like compounds. The existence of a hydrated $\mathrm{Pd}-\mathrm{O}$ compound is suggested, and its dehydration or deoxygenation at low temperatures may account for the $\mathrm{O}$-deficient $\mathrm{Pd}$-rich species, interpreted as a transient phase toward native palladium. Although gypsum is a common mineral in the oxidized (supergene) zones of gold deposits, the hematite-gypsumbearing palladian gold nugget was tectonically deformed under brittle conditions and appears to be of low-temperature hydrothermal origin.
\end{abstract}

Keywords: ouro preto, hematite-gypsum mineral assemblage, Pd-bearing gold, $\mathrm{Pd}-\mathrm{O}$ coating, isomertieite, mertieite-II, Gongo Soco, Minas Gerais, Brazil.

SOMMAIRE

Une pépite de ouro preto (or noir) provenant de Gongo Soco, Minas Gerais, au Brésil, contient l'assemblage hématite + gypse dans un hôte d'or palladifère. L'hématite en inclusion est microfissurée et étirée. La surface de la pépite est recouverte d'un matériau foncé qui correspond en partie à une gaine de $\mathrm{Pd}-\mathrm{O}$ avec des reliques d'arséniures et d'antimoniures de palladium dont la composition ressemble à celles de isomertieïte et mertieïte-II. Cette couche à $\mathrm{Pd}-\mathrm{O}$ contient des quantités importantes de Cu, Fe et $\mathrm{Hg}$, et montre un rapport variable de métal à oxygène, allant de matériau déficitaire en oxygène à des composés ressemblant à des oxydes. A notre avis, il y a des indications d'un composé $\mathrm{Pd}-\mathrm{O}$ hydraté, et sa déshydratation ou sa perte en oxygène à faibles températures rendrait compte des variétés riches en $\mathrm{Pd}$ et appauvries en $\mathrm{O}$, que nous interprétons comme phases transitoires dans une progression vers le palladium natif. Quoique le gypse est un minéral répandu dans la zone oxydée (supergène) des gisements d'or, la pépite d'or palladifère à hématite-gypse a été déformée tectoniquement sous conditions cassantes, et semble avoir une origine hydrothermale à faible température.

(Traduit par la Rédaction)

Mots-clés: ouro preto, assemblage à hématite-gypse, or palladifère, gaine riche en Pd-O, isomertieïte, mertieïte-II, Gongo Soco, Minas Gerais, Brésil.

§E-mail addresses: cabral@min.tu-clausthal.de,rogerio.kwitko@cvrd.com.br 


\section{INTRODUCTION}

Recently, investigators have provided evidence for epigenetic, sulfide-poor, hydrothermal mineralization of palladium and platinum (e.g., Cabral et al. 2002a, Fleet et al. 2002, Grainger et al. 2002, Kwitko et al. 2002, Nickel 2002, Sener et al. 2002, Stanley et al. 2002, and references therein). However, the occurrence of Pd- and Pt-bearing minerals in highly oxidized mineral assemblages had already clearly been indicated in much earlier works (e.g., Johnson \& Lampadius 1837, Henwood 1871, Hussak 1904, Ball \& Shaler 1914, Knopf 1915, Wagner 1929). One of the most extraordinary cases described in the so-called "old literature" refers to the singular nuggets of ouro preto (black gold). Ouro Preto was so abundant in Villa Rica that the town was renamed Ouro Preto, the most sumptuous baroque village of the Brazilian Gold Cycle ( $c a$. 1695-1785). Much of the ouro preto from the Ouro Preto area was presumedly recovered from itabirite-hosted, Pd-bearing gold mineralization, known as jacutinga (e.g., Hartt 1870, Scott 1902, Hussak 1904).

In the 19th century, Gongo Soco was the most important jacutinga-style gold deposit in Minas Gerais. The deposit is situated about $50 \mathrm{~km}$ north-northwest from Ouro Preto; Cabral et al. (2002b) provide a location map. Possibly, the first chemical investigation of ouro preto started there. In 1826, during his residence at Gongo Soco, Daniel Gardner (physician and mineralogist working for the Imperial Brazilian Mining Association) was not only capable of identifying palladium, but also of finding out that palladium was contained within Fe-rich oxide material: “... the remaining powder [crushed ore] ... produced a steel grey coloured amalgam weighing five grains, and one grain eighttenths, after cupellation, of palladium, without gold, a circumstance altogether new, never having found it before but in combination with that metal. ... the greater part of the palladium remaining yet in the iron sand" (Gardner 1826, p. 117). This was probably the first indication that the Gongo Soco gold was associated with an Fe-rich $\mathrm{Pd}-\mathrm{O}$ phase, a fact later confirmed by Johnson \& Lampadius (1837) and Cabral et al. (2001). A review of the historical descriptions of ouro preto was given by Jedwab \& Cassedanne (1998).

At present, Gongo Soco is an iron ore mine. The mine pit has recently exposed (at a depth of about $15 \mathrm{~m}$ ) remains of old underground workings of the former gold mine, making it possible to recover ouro preto nuggets from cross-cutting, specular-hematite-rich auriferous veins hosted by itabirite (Cabral et al. 2002b). Results of chemical analyses by Percival Norton Johnson (reported in Henwood 1871 and Hussak 1904) indicated that the gold is alloyed with palladium. Electron-microprobe analyses confirmed the existence of palladian gold and demonstrated an inclusion assemblage of palladium arsenide-antimonides, compositionally close to mertieite-II and isomertieite (Cabral et al. 2002b). One nugget of gold has been found with an inclusion assemblage of gypsum and hematite, partially coated by a dark $\mathrm{Pd}-\mathrm{O}$ phase. This particular ouro preto nugget is described herein.

\section{The Hematite-Gypsum-Bearing OURo PRETo Nugget}

A nugget of gold, about $0.7 \mathrm{~cm}$ in length, was recovered in a Knelson concentrator at the iron ore plant. The nugget is partially coated by a black to reddish brown material, which gives the characteristic dark-colored appearance to the ouro preto (Fig. 1a). Microscopic investigation of a polished cross-section of the nugget shows inclusions of hematite and a gangue mineral, as well as a low-reflectance coating (Fig. 1b). The dark coating has relics of a higher-reflectance phase (Fig. 1c). Electron-microprobe analyses indicate that the gold is alloyed with about 6 wt.\% $\mathrm{Ag}$ and $1 \mathrm{wt} . \% \mathrm{Pd}$, whereas the mineral relics in the dark coating are palladium arsenide-antimonides compositionally analogous to isomertieite and mertieite-II (Table 1).

The gangue mineral, approximately $160 \mu \mathrm{m}$ in length, is euhedral (Fig. 2a) and has a homogeneous distribution of calcium and sulfur (Figs. 2b, c). During the reconnaissance energy-dispersion (ED) analysis, the incidence of the electron beam produced cavities, of about $5 \mu \mathrm{m}$ in diameter (Fig. 2a), indicative of loss of $\mathrm{H}_{2} \mathrm{O}$ from a hydrated calcium sulfate (gypsum). The euhedral crystal of hematite included in gold is microfractured and segmented (Fig. 3).

A relic of isomertieite in the dark coating is shown in Figure 4a. X-ray mapping shows that antimony is restricted to the relic (Fig. 4b), but that palladium and oxygen are dispersed throughout the matrix (Figs. 4c, d). Iron is concentrated in the lower half of the area (Fig. 4e), where the matrix has a "fibrous" microstructure (Fig. 4a). The iron-rich areas match those of higher oxygen content, which may correspond to a Pd-bearing $\mathrm{Fe}-\mathrm{O}$ compound. Copper and, less abundantly, mercury are also present in the matrix (Figs. 4f, g). During the $\mathrm{X}$-ray mapping, arrays of microcracks appeared in the upper part of the area (Fig. 4a), suggesting the presence of a hydrated $\mathrm{Pd}-\mathrm{O}$ compound.

Quantitative electron-microprobe analyses of the dark coating of $\mathrm{Pd}-\mathrm{O}$ are hampered by the irregular and poorly polished surface, formation of microcracks and, possibly, interference from gold. Furthermore, rather extreme analytical conditions for oxygen were used, compared to those reported in Augé \& Legendre (1994). These are the reasons why the electron-microprobe data of Table 2 are not totally reliable and should be considered with caution. The data point to a variable metal:oxygen ratio, from oxygen-deficient compounds, approaching a $\mathrm{Pd}-\mathrm{Cu}$ alloy (Table 2, column 2), to ratios close to $1: 1$ and 1:2, suggesting compounds similar to $(\mathrm{Pd}, \mathrm{Cu}) \mathrm{O}$ and $(\mathrm{Fe}, \mathrm{Pd}) \mathrm{OOH}$, respectively (Table 2, columns 4 and 5 ). 

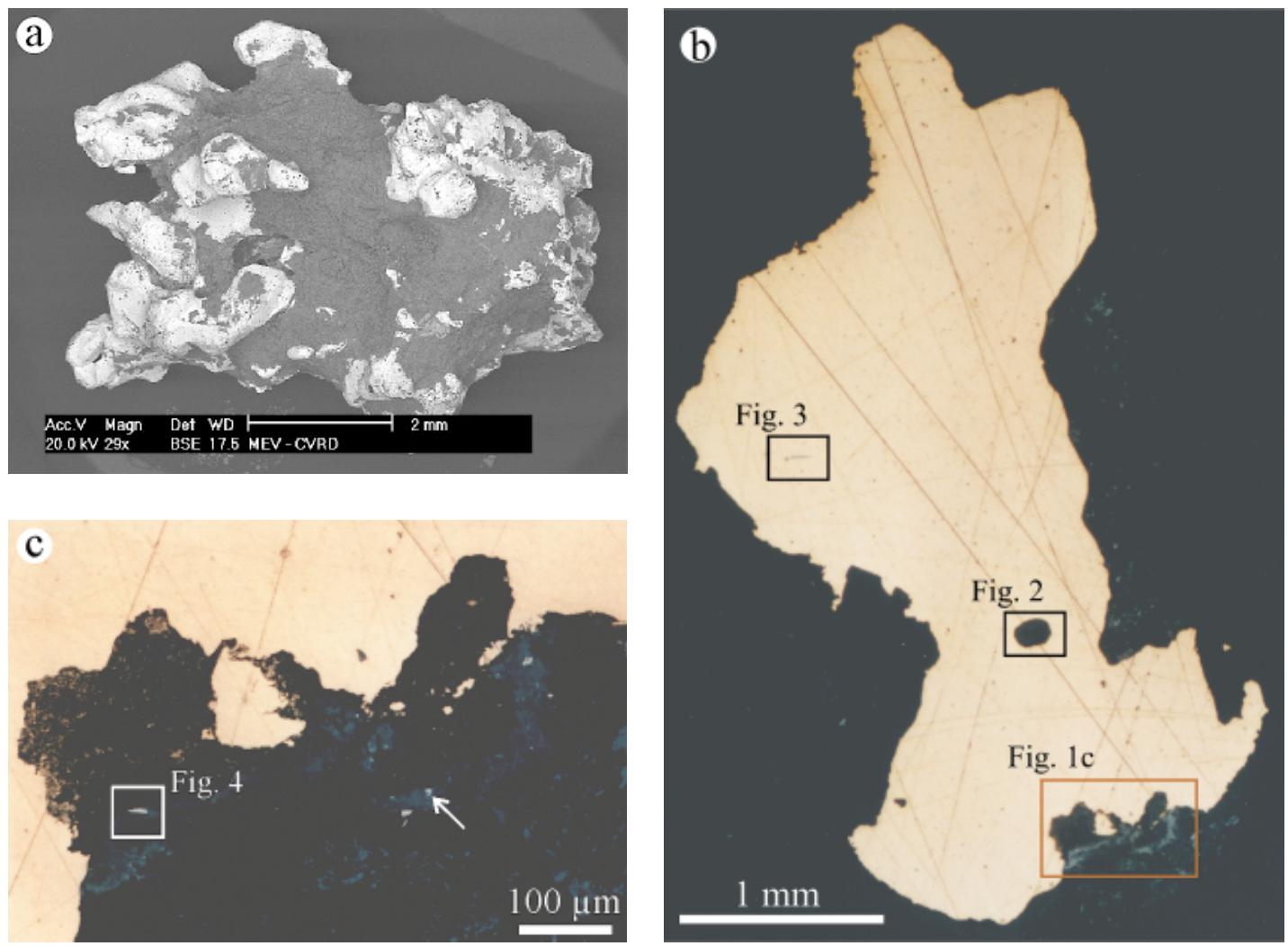

FIG. 1. a. Back-scattered electron (BSE) image of the gold nugget investigated in this study, with the dark appearance that characterizes ouro preto. b. Reflected-light photomicrograph (in air) of a polished cross-section of the nugget shown in (a). c. Reflected-light photomicrograph (in oil) of the area indicated in (b), in which a relic of isomertieite (white) is outlined. The arrow denotes a relic of mertieite-II (white). The dark matrix is composed of a goethite-like material with fine-grained crystals of platy hematite.
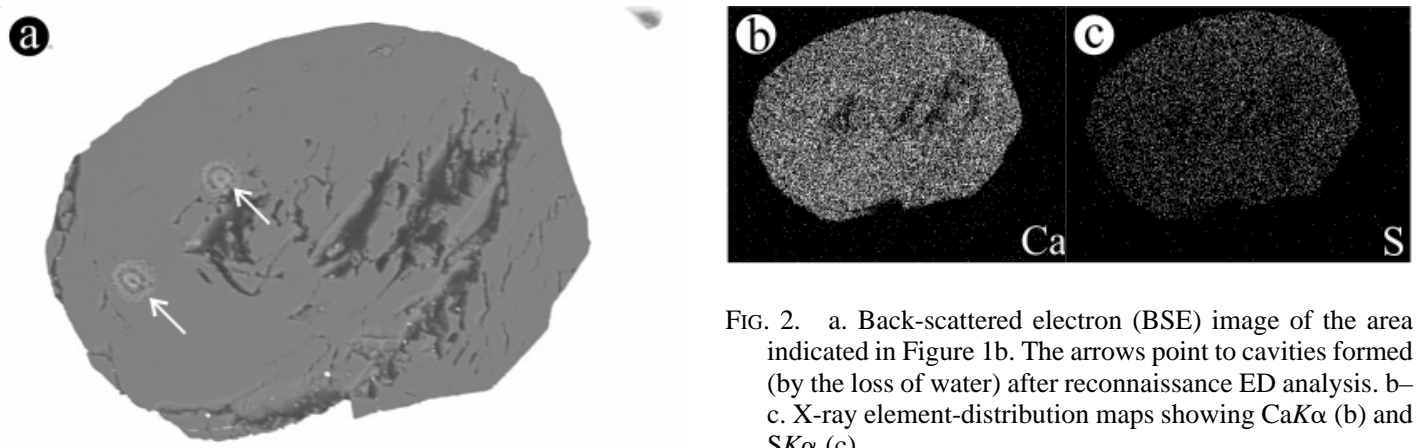

FIG. 2. a. Back-scattered electron (BSE) image of the area indicated in Figure 1b. The arrows point to cavities formed (by the loss of water) after reconnaissance ED analysis. bc. X-ray element-distribution maps showing $\mathrm{CaK \alpha}(\mathrm{b})$ and $\mathrm{S} K \alpha(\mathrm{c})$. 


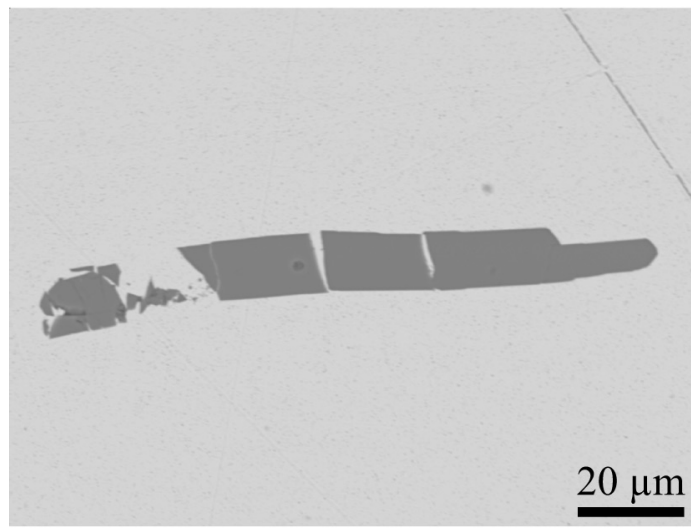

FIG. 3. BSE image of the hematite crystal indicated in Figure $1 \mathrm{~b}$. Note that the hematite is microfractured and stretched.

\section{Discussion AND CONCLUSIONS}

The occurrence of gypsum as an inclusion in Pdbearing gold has not, to the authors' knowledge, been previously reported. Gypsum is a common mineral in the oxidized zones of auriferous deposits (Boyle 1979). It is also well known that gypsum occurs as efflorescences ("desert roses") by evaporation in the dry season, and is found as a gangue mineral in gold-quartz deposits (Lindgren 1928, Boyle 1979). The temperature of breakdown of gypsum to anhydrite $+\mathrm{H}_{2} \mathrm{O}$ in pure water is $49 \pm 2.5^{\circ} \mathrm{C}$ (Innorta et al. 1980), and is considerably lowered by the presence of $\mathrm{NaCl}$ (Blount \& Dickson 1973). Therefore, gypsum is expected to be encountered only in low-temperature hydrothermal deposits or in the supergene zone (Holland 1967). One may speculate that thiosulfate could have been involved in the transport of gold in order to form a gold-gypsum-hematite paragenesis (e.g., Kucha et al. 1994). However, gypsum has hitherto been observed in only one nugget of gold from Gongo Soco, and sulfide minerals, the expected result of disproportionation of thiosulfate, are characteristically lacking. Whatever its origin, the presence of gypsum and hematite indicates highly oxidizing conditions of nugget formation at Gongo Soco.

The hematite crystal of Figure 3 is segmented. Other similar nuggets of gold in the suite, though lacking gypsum, have microfractured inclusions of isomertieite and mertieite-II, commonly with fissures healed by the host Pd-bearing gold (Cabral et al. 2002b). In some instances, coarse-grained palladian gold is cross-cut by veinlets of specular hematite, kaolinite and fine-grained palladian gold (Cabral \& Lehmann 2003). These microstructures indicate that the gold nuggets were subjected to a late-stage tensile stress field under brittle conditions. Such a tectonic setting is more likely to have occurred
TABLE 1. RESULTS OF ELECTRON-MICROPROBE ANALYSES OF GOLD AND PALLADIUM ARSENIDE-ANTIMONIDES

\begin{tabular}{lrrrrr}
\hline & & & & & \\
& 1 & 2 & 3 & 4 & 5 \\
\hline & & & & & \\
Au wt.\% & 92.63 & 92.94 & 92.91 & 3.71 & 0.95 \\
$\mathrm{Pd}$ & 0.96 & 0.84 & 0.91 & 72.31 & 73.10 \\
$\mathrm{Ag}$ & 6.13 & 6.27 & 6.11 & $<0.3$ & $<0.3$ \\
$\mathrm{Cu}$ & 0.19 & 0.11 & 0.11 & 1.15 & 0.48 \\
$\mathrm{Fe}$ & $<0.05$ & $<0.05$ & $<0.05$ & 0.26 & 0.13 \\
$\mathrm{Sn}$ & $<0.03$ & $<0.03$ & $<0.03$ & 0.05 & 0.09 \\
$\mathrm{Sb}$ & $<0.03$ & $<0.03$ & $<0.03$ & 14.46 & 25.36 \\
$\mathrm{As}$ & $<0.15$ & $<0.15$ & $<0.15$ & 9.87 & 2.08 \\
& & & & & \\
Total & 99.91 & 100.16 & 100.04 & 101.81 & 102.19 \\
& & & & &
\end{tabular}

The electron-microprobe analyses were performed at $20 \mathrm{kV}$ and $40 \mathrm{nA}$ with a Cameca SX100 (TU Clausthal). The following X-ray lines and standards were used: pure metals $(\mathrm{Ag} L \beta, \mathrm{Au} L \alpha, \mathrm{Cu} K \alpha, \mathrm{Pd} L \alpha$ and $\mathrm{Pt} L \alpha), \mathrm{HgTe}(\mathrm{Hg} L \alpha), \mathrm{Fe}_{2} \mathrm{O}_{3}(\mathrm{Fe} K \alpha), \mathrm{SnO}_{2}$ $(\mathrm{Sn} L \alpha), \operatorname{InSb}(\mathrm{Sb} L \alpha)$ and $\operatorname{InAs}(\operatorname{As} L \alpha)$. Platinum and mercury were sought, but are below the detection limit, $0.3 \mathrm{wt} \%$. Column headings: 1-3: gold, 4: isomertieite, 5 : mertieite-II.

TABLE 2. RESULTS OF ELECTRON-MICROPROBE ANALYSES OF THE DARK COATING ON OURO PRETO

\begin{tabular}{|c|c|c|c|c|c|}
\hline & 1 & 2 & 3 & 4 & 5 \\
\hline Pd wt.\% & 73.74 & 78.18 & 79.17 & 41.47 & 65.86 \\
\hline As & 0.29 & 0.44 & $<0.09$ & 0.41 & 0.76 \\
\hline $\mathrm{Cu}$ & 7.42 & 11.47 & 10.24 & 5.04 & 9.83 \\
\hline $\mathrm{Fe}$ & 4.73 & 0.19 & 0.23 & 24.89 & 1.36 \\
\hline $\mathrm{Mn}$ & 0.38 & 0.42 & 0.48 & 0.39 & 0.32 \\
\hline $\mathrm{Hg}$ & 2.64 & 1.81 & 0.84 & 2.13 & 3.65 \\
\hline $\mathrm{Au}$ & 1.55 & 3.39 & 6.65 & 1.04 & 2.84 \\
\hline $\mathrm{O}$ & 3.85 & 1.58 & 2.47 & 29.13 & 12.06 \\
\hline Total & 94.60 & 97.48 & 100.08 & 104.50 & 96.68 \\
\hline Pd $a p f u$ & 1.19 & 1.39 & 1.34 & 0.42 & 0.77 \\
\hline As & 0.01 & 0.01 & - & 0.01 & 0.01 \\
\hline $\mathrm{Cu}$ & 0.20 & 0.34 & 0.29 & 0.09 & 0.19 \\
\hline $\mathrm{Fe}$ & 0.15 & 0.01 & 0.01 & 0.48 & 0.03 \\
\hline $\mathrm{Mn}$ & 0.01 & 0.01 & 0.02 & 0.01 & 0.01 \\
\hline $\mathrm{Hg}$ & 0.02 & 0.02 & 0.01 & 0.01 & 0.02 \\
\hline $\mathrm{Au}$ & 0.01 & 0.03 & 0.06 & 0.01 & 0.02 \\
\hline Emetals & 1.59 & 1.81 & 1.72 & 1.02 & 1.06 \\
\hline $\mathrm{O}$ & 0.41 & 0.19 & 0.28 & 1.98 & 0.94 \\
\hline$\Sigma a p f u$ & 2 & 2 & 2 & 3 & 2 \\
\hline
\end{tabular}

Analytical conditions as in Table 1, with additional standards as follows: $\mathrm{MnSiO}_{3}$ $(\mathrm{Mn} K \alpha), \mathrm{HgTe}(\mathrm{Hg} L \alpha)$ and $\mathrm{Al}_{2} \mathrm{O}_{3}(\mathrm{O} K \alpha)$. Antimony and platinum were sought, but are below the detection limit, 0.1 and $0.4 \mathrm{wt} . \%$, respectively. See Figure $4 \mathrm{a}$ for the location of the points analyzed.

in hypogene conditions rather than as a result of weathering.

The dark Pd-O-bearing coating contains relics of isomertieite and mertieite-II and may have been derived, at least in part, by oxidation of these minerals. The oxidation process may have involved leaching of antimony and arsenic from the pre-existing palladium arsenideantimonide, and incorporation of external metals, like iron and manganese, into $\mathrm{Pd}-\mathrm{O}$. The mercury in this assemblage was seemingly extraneous, as it was not detected in the relics. 


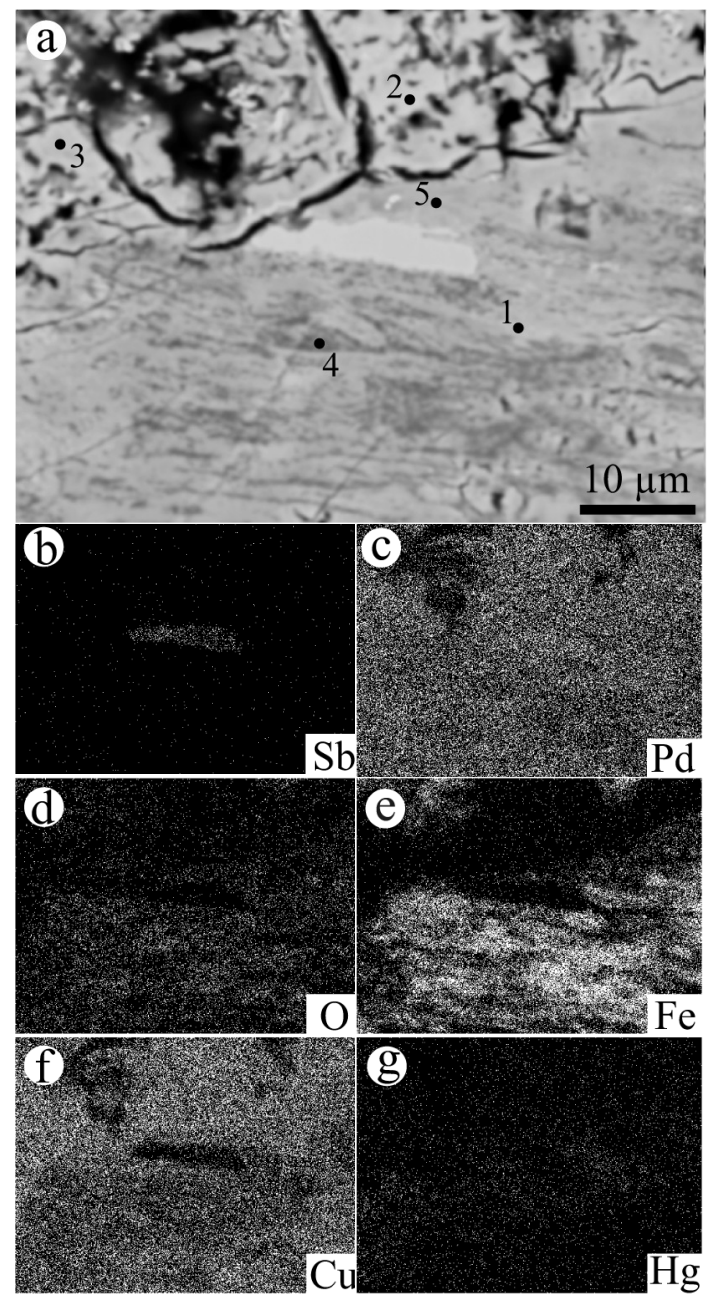

FIG. 4. a. BSE image of the area outlined in Figure 1c. Microcracks (upper part) were formed during the X-ray mapping. The numbers refer to column numbers in Table 2. The mineral phase at the center (white) has a composition close to isomertieite. b-g. X-ray element-distribution maps showing $\mathrm{Sb} L \alpha$ (b), $\mathrm{Pd} L \alpha$ (c), $\mathrm{O} K \alpha$ (d), $\mathrm{Fe} K \alpha$ (e), $\mathrm{CuK \alpha}$ (f) and $\operatorname{Hg} L \alpha(\mathrm{g})$.

Although the electron-microprobe data cannot be used for quantitative purposes (i.e., evaluation of empirical stoichiometries), they provide evidence for a hydrated $\mathrm{Pd}-\mathrm{O}$ compound. There is indication of a natural hydrated oxide of palladium in a dunite zone affected by the seasonal movement of groundwater near Lavatravo, Andriamena area, Madagascar (McDonald et al. 1999). Those authors suggested that a precursor Pd-rich mineral was leached and replaced by oxygen and $\mathrm{H}_{2} \mathrm{O}$ to form hydrated palladium oxide at the watertable interface. McDonald et al. (1999) also proposed that hydrated palladium oxide may repeatedly be heated during the tropical dry season, eventually dehydrating to native palladium. Not only could this dehydrationdeoxygenation mechanism ( $c f$. Cabral \& Lehmann 2003) explain the formation of the native palladium found by Salpéteur et al. (1995), but also the oxygendeficient $\mathrm{Pd}-\mathrm{Cu}$ phase reported here (Table 2, column 2 ), which may represent an intermediate (metastable) phase between hydrated palladium oxide and native palladium.

The sample material (polished section) described in this contribution has been deposited at the mineral collection of the Centro de Desenvolvimento Mineral, Companhia Vale do Rio Doce (Rodovia BR 262/km 296, Caixa Postal 09, 33030-970 Santa Luzia - MG, Brazil), catalogued as QF/GS-Au-3b.

\section{ACKNOWLEDGEMENTS}

ARC gratefully acknowledges a doctoral scholarship by the Deutscher Akademischer Austauschdienst (DAAD). This work would not have been possible without the logistical support of the former Mineração Socoimex and of the current owner of the Gongo Soco mine, Companhia Vale do Rio Doce (CVRD). ARC is particularly indebted to the Gongo Soco staff, specially Antônio Abdo, Muriel Innocentini, Toco, Edivando and Pimenta, for the inestimable assistance in the field work. Klaus Herrmann (TU Clausthal) patiently helped in the micro-analytical work. The thoughtful comments by Jacques Jedwab and Kari Kojonen, as well as the suggestions and the careful editorial handling by Nigel J. Cook and Robert F. Martin, helped to improve the manuscript and are gratefully acknowledged.

\section{REFERENCES}

Augé, T. \& Legendre, O. (1994): Platinum-group element oxides from the Pirogues ophiolitic mineralization, New Caledonia, origin and significance. Econ. Geol. 89, 14541468.

BALL, S.H. \& SHALER, M.K. (1914): Economic geology of the Belgian Congo, central Africa. Econ. Geol. 9, 605-663.

Blount, C.W. \& Dickson, F.W. (1973): Gypsum-anhydrite equilibria in systems $\mathrm{CaSO}_{4}-\mathrm{H}_{2} \mathrm{O}$ and $\mathrm{CaSO}_{4}-\mathrm{NaCl}-\mathrm{H}_{2} \mathrm{O}$. Am. Mineral. 58, 323-331.

BoyLe, R.W. (1979): The geochemistry of gold and its deposits. Geol. Surv. Can., Bull. 280.

CABral, A.R. \& LEHMAnN, B. (2003): A two-stage process of native palladium formation at low temperatures: evidence from a palladian gold nugget (Gongo Soco iron ore mine, Minas Gerais, Brazil). Mineral. Mag. 67 (in press). 
Kwitko, R. \& Cravo Costa, C.H (2002a): The Serra Pelada Au-Pd-Pt deposit, Carajás mineral province, northern Brazil: reconnaissance mineralogy and chemistry of very-high-grade palladian gold mineralization. Econ. Geol. 97, 1127-1138.

\& Jones, R.D. (2002b):

Palladian gold and palladium arsenide-antimonide minerals from Gongo Soco iron ore mine, Quadrilátero Ferrífero, Minas Gerais, Brazil. Trans. Inst. Mining Metall. (Sect. B: Appl. Earth Sci.) 111, 74-80.

PIRES, F.R.M., Rocha Filho, O.G. \& InNocentini, M.D. (2001): Palladium-oxygenated compounds of the Gongo Soco mine, Quadrilátero Ferrífero, central Minas Gerais, Brazil. Mineral. Mag. 65, 169-179.

Fleet, M.E., De Almeida, C.M. \& Angeli, N. (2002): Botryoidal platinum, palladium and potarite from the Bom Sucesso stream, Minas Gerais, Brazil: compositional zoning and origin. Can. Mineral. 40, 341-355.

GARDNER, D. (1826): In Imperial Brazilian Mining Association - Reports of the directors addressed to the share-holders. The Philanthropic Society, London, 117-119.

Grainger, C.J., Groves, D.I. \& Cravo Costa, C.H. (2002): The epigenetic sediment-hosted Serra Pelada Au-PGE deposit and its potential genetic association with Fe-oxide $\mathrm{Cu}-\mathrm{Au}$ mineralisation within the Carajás mineral province, Amazon craton, Brazil. In Hydrothermal Iron Oxide Copper-Gold \& Related Deposits: a Global Perspective 2 (T.M. Porter, ed.). PGC Publishing, Adelaide, Australia (227245).

HaRtT, C.F. (1870): Geology and Physical Geography of Bra$z i l$. Fields, Osgood, and Co., Boston, Massachusetts.

Henwood, W.J. (1871): On the gold mines of Minas Geraes, in Brazil. Trans. R. Geol. Soc. Cornwall 8, 168-370.

Holland, H.D. (1967): Gangue minerals in hydrothermal systems. In Geochemistry of Hydrothermal Ore Deposits (H.L. Barnes, ed.). Holt, Rinehart \& Winston, New York, N.Y. (382-436).

HussaK, E. (1904): Über das Vorkommen von Palladium und Platin in Brasilien. Sitzungsberichte der mathematischnaturwissenschaftlichen Klasse der Kaiserlichen Akademie der Wissenschaften 113, 379-468.

InNorta, G., RABBI, E. \& Tomadin, L. (1980): The gypsumanhydrite equilibrium by solubility measurements. Geochim. Cosmochim. Acta 44, 1931-1936.

JEDWAB, J. \& CASSEDANNE, J. (1998): Historical observations on oxygen-bearing compounds of platinum and palladium in Minas Gerais, Brazil. Can. Mineral. 36, 887-893.
Johnson, P.N. \& LAMPADIUS, W.A. (1837): Ueber brasilianisches Palladgold und dessen Ausbringen und Scheidung. Journal für praktische Chemie 11, 309-315.

KNOPF, A. (1915): A gold - platinum - palladium lode in southern Nevada. U. S. Geol. Surv., Bull. 620-A.

Kucha, H., Stumpfl, E.F., Plimer, I.R. \& KöcK, R. (1994): Gold-pyrite association - result of oxysulphide and polysulphide transport of gold? Trans. Inst. Mining Metall. (Sect. B: Appl. Earth Sci.) 103, 197-205.

Kwitko, R., Cabral, A.R., Lehmann, B., Laflamme, J.H.G., CABri, L.J., CRiddle, A.J. \& Galbiatti, H.F. (2002): Hongshiite, $\mathrm{PtCu}$, from itabirite-hosted $\mathrm{Au}-\mathrm{Pd}-\mathrm{Pt}$ mineralization (jacutinga), Itabira district, Minas Gerais, Brazil. Can. Mineral. 40, 711-723.

Lindgren, W. (1928): Mineral Deposits. McGraw-Hill, New York, N.Y

McDonald, I., Ohnenstetter, D., Ohnenstetter, M. \& VAughan, D.J. (1999): Palladium oxides in ultramafic complexes near Lavatrafo, Western Adriamena, Madagascar. Mineral. Mag. 63, 345-352.

NicKel, E.H. (2002): An unusual occurrence of Pd, Pt, Au, Ag, and $\mathrm{Hg}$ minerals in the Pilbara region of Western Australia. Can. Mineral. 40, 419-433.

Salpéteur, I., Martel-Jantin, B. \& Rakotomanana, D. (1995): Pt and Pd mobility in ferralitic soils of the West Adriamena area (Madagascar): evidence of a supergene origin of some Pt and Pd minerals. Chronique de la Recherche Minière 63(520), 27-45.

ScotT, H.K. (1902): The gold field of the state of Minas Geraes, Brazil. Trans. Am. Inst. Mining Eng. 33, 406-444.

Syener, A.K., Grainger, C.J. \& Groves, D.I. (2002): Epigenetic gold-platinum-group element deposits: examples from Brazil and Australia. Trans. Inst. Mining Metall. (Sect. B: Appl. Earth Sci.) 111, 65-73.

Stanley, C.J., Criddle, A.J., Förster, H.-J. \& Roberts, A.C. (2002): Tischendorfite, $\mathrm{Pd}_{8} \mathrm{Hg}_{3} \mathrm{Se}_{9}$, a new mineral species from Tilkerode, Harz Mountains, Germany. Can. Mineral. 40, 739-745.

Wagner, P.A. (1929): The Platinum Deposits and Mines of South Africa. Oliver and Boyd, Edinburgh, U.K.

Received November 3, 2002, revised manuscript accepted March 7, 2003. 